\title{
Characterization of GPX1 and DIO1 Genes in
}

\section{Bubalus Bubalis}

\author{
Vandana Dureja \\ National Bureau of Animal Genetic Resources \\ P O Box-129, GT By pass road, Karnal-132001, Haryana, India \\ Singhania University, Pacheri Bari (Jhunjhunu), Rajasthan, India \\ E-mail: vdureja88@gmail.com
}

Sumer Singh

Singhania University, Pacheri Bari (Jhunjhunu), Rajasthan, India

E-mail: sumy_1980@rediffmail.com

\section{S Rana}

National Bureau of Animal Genetic Resources,

P O Box-129, GT Bypass road, Karnal-132001, Haryana, India

E-mail: rshivani87@gmail.com

\section{P Banerjee}

National Bureau of Animal Genetic Resources

P O Box-129, GT Bypass road, Karnal-132001, Haryana, India E-mail: priyankabnrj@gmail.com

\section{J Joshi}

National Bureau of Animal Genetic Resources

P O Box-129, GT Bypass road, Karnal-132001, Haryana, India

E-mail: jyotijoshi111@gmail.com 


\author{
M S Tantia (Corresponding author) \\ National Bureau of Animal Genetic Resources \\ P O Box-129, GT Bypass road, Karnal-132001, Haryana, India \\ Tel: 09-416-296-105, E-mail: tantiams@gmail.com \\ R K Vijh \\ National Bureau of Animal Genetic Resources \\ P O Box-129, GT Bypass road, Karnal-132001, Haryana, India \\ E-mail: rameshkvijh@gmail.com
}

Received: September 28, 2012 Accepted: October 10, 2012

doi:10.5296/jbls.v4i1.2872

URL: http://dx.doi.org/10.5296/jbls.v4i1.2872

\begin{abstract}
Selenoprotein genes contain selenium in the form of selenocysteine which is involved in protecting the cells from oxidative stress. Soils in India differ greatly in selenium concentrations affecting feed stuffs for selenium availability. Selenoproteins have recently been identified in variety of living organisms including humans which have 25 selenoprotein genes. Among these families of selenoprotein genes, we sequenced Gpx1 gene (Glutathione peroxidases1) and Dio1 gene (Iodothyronine deiodinases) in Bubalus bubalis. Gpx1 is most abundant and ubiquitously expressed selenoprotein which helps to protect against the damaging effects of hydrogen peroxide and oxygen rich free radicals whereas Dio1 is expressed mainly in liver, thyroid gland and adipose tissue, its main function is to convert tetraiodothyronine (T4) to its active form thyroxine (T3) in the presence of deiodinases enzyme. The main aim of the study was to characterize these two genes and to find out the buffalo specific SNPs. This was accomplished by designing primers using cattle database and sequencing a panel of 24 samples consisting of 6 diverse breeds of buffalo. Gpx 1 consisted of 2 exons (Accession ID: JQ031269) while Dio1 comprised 4 exons (Accession ID: JQ791197). In Gpx1 gene, 9 SNPs were recorded and 4 were non synonymous, changing amino acid were distributed equally in both exon. In exon 1, A141G (aa Q5R) and G161A (aa A12T); and in exon 2 C785T (aa R132W) and A808T (aa S139R). In Dio1 gene, 3 non synonymous SNPs were identified at A188G (aa H22R), C215G (aa T31R) and G941A (aa V146I). These SNPs are novel and reported for the first time in Indian buffalo and has a potential for their use in diversity analysis and association with various selenium related traits.
\end{abstract}


Keywords: Selenoproteins, DIO1, GPX1, Single nucleotide polymorphism, Bubalus bubalis

\section{Introduction}

Buffaloes are the richest livestock genetic resource that is found in abundance in India and form the important component of the livelihood of rural masses in India. Buffalo husbandry is an important source of income and employment for a large number of the farmers. It is the main plank for the development of dairy industry in India, contributing a major share (56\%) of total milk production in India. Over the years intense research has been carried out on health of dairy cows. Various conditions including poor nutrition and pathogens are responsible for poor growth and lower productivity, lower productivity is caused by disruption of normal physiological processes and the fundamental reason why these diseases occur is the impairment of dairy cow immunity (Mehrzad et al., 2001; Burvenich et al., 2003; Paape et al., 2003). Due to low status of selenium, dairy cows are more vulnerable to intramammary infections (IMIs) (Smith et al., 1984; 1987; Malbe et al., 1995; 2003; Weiss and Hogan, 2005). Selenium (Se) is an essential trace element and is an integral component of a variety of proteins or enzymes known as selenoproteins. Selenium serves various functions such as immune functions; it improves reproduction efficiencies functions as antioxidant and even has anticarcinogenic properties (Rayman, 2000; Spears, 2000). Selenium therefore if not present in desired amount can cause lower health status and productivity in dairy animals. Dairy animals intake selenium from plant sources which in turn depend on selenium content of the soils in which they are grown. The selenoprotein distribution and concentration in animal tissues depends upon dietary sources of minerals (WHO, 1987; Gibson, 1990).

About 25 different selenocysteine-containing selenoproteins have so far been observed in human cells and tissues which can be grouped into five distinct families: Iodothyronine deiodinases (DIO1, DIO2, DIO3); Glutathione peroxidases (GPX1, GPX2, GPX3, GPX4, GPX6); Selenoproteins (SelH, SelI, SelK, SelM, SelN, SelO, SelP, SelR, SelS, SelT, SelV, SelW, Sel15); Selenophosphate synthetase 2 (SPS2); Thioredoxin reductases 1-3: (TXNRD1, TXNRD2, TXNRD3). In the present study we focused on GPX1 and DIO1 gene in Bubalus bubalis which is mapped to chromosome 21 and chromosome 6 respectively. In 1950s it was reported that selenium is an essential trace element for mammals and also a component of enzyme, glutathione peroxidase (GSH-Px) (Schwarz and Foltz, 1957; Flohé et $a l ., 1973)$. Like selenium status oxidative stress also influences the expression of GPx1. GSH-Px is an enzyme that provides antioxidative defense in mammals by converting hydrogen peroxide to water and lipid hydroperoxides to the corresponding alcohols. Selenium is integrated into GSH-Px as a selenocysteine residue, and is responsible for the catalytic efficiency of the enzyme (Forstrom et al., 1978; Wendel et al., 1978; Rocher et al., 1992; Aumann et al., 1997). GPx1 uses GSH (Glutathione) to reduce ROS (Reactive oxygen species), producing GSSG (Glutathione disulfide) in the process, which is converted back to GSH by the enzyme Glutathione reductase (Reeves et al., 2009). This protein is one of the lesser known found in higher vertebrates to contain selenocysteine, which occurs at the active site of glutathione peroxidase and is coded by UGA, which normally functions as a translation termination codon. 
Thyroid hormones are important regulators of mammalian development, cellular differentiation and metabolism (Ingbar et al., 1986). Thyroxine (T4), which is the primary hormone secreted by the thyroid has little intrinsic biological activity due to low affinity for nuclear thyroid hormone receptors. When mono deiodination of the outer ring (5'-deiodination) of T4 occurs, it yields T3 thyroid hormone which has much greater biological activity, whereas deiodination of the inner ring (5-deiodination) converts T4 and T3 to the biologically inert compounds, 3,3',5'-triiodothyronine (reverse T3, rT3) and 3,3'-diiodothyronine (3,3'-T2), respectively. The main activity of thyroid hormones is regulated by three deiodinases. The 5'-deiodination is catalyzed by type-I (DIO1) and type-II (DIO2) deiodinases present in many tissues. Expression of DIO1 occurs predominantly in thyroid, liver and kidney, and whereas DIO2 is expressed mainly in pituitary, brain, brown adipose tissue and placenta (St. Germain DL, 1994; Gereben B et al., 2008). Depending upon species, DIO1 or DIO2 may be expressed in mammary gland of bovines and other animals.

Thus, this study was undertaken to characterize GPX1 and DIO1 genes in Bubalus bubalis and to detect SNPs in these two genes.

\section{Materials and Methods}

The GPX1 and DIO1 genes were characterized in a panel of 24 animals drawn from six Indian buffalo breeds (Murrah, Pandharpuri, Toda, Banni, Chilika, Manipuri). The Murrah breed is a north Indian large dairy breed. The Murrah buffalo is the finest genetic material of milk producing buffalo in the world. The Pandharpuri buffaloes are medium sized buffaloes from central India while Banni is a western India dairy breed. The Toda breed is mostly reared in South India. Chilika is small sized population mostly adapted to eastern regions of Orissa. The north eastern states like Manipur, Mizoram etc. have sizable population of Manipuri buffaloes (Mishra, 2010), which are of swamp type $(2 n=48)$.

The exonic regions were amplified by designing primers in exon-intron boundaries for GPX1 and DIO1 genes. These primers were designed from sequence available in Bovine Ensembl Transcript for GPX1 (ENSBTAG00000004274) and DIO1 (ENSBTAG00000010814). All PCR primers were designed using web interface of Primer3. PCR primers for amplification of both the genes are given in Table 1. Cattle genomic DNA was used as a control. The genes were sequenced and submitted to NCBI with accession numbers JQ031269 and JQ791197 respectively. The reaction volume of $15 \mu \mathrm{l}$ containing 50ng of template DNA, 5 pmol of each primer, $0.2 \mu \mathrm{mol}$ of each dNTP, 1 unit of Taq DNA polymerase (Sigma) with 1 X PCR buffer and $2.0 \mathrm{mM} \mathrm{MgCl} 2$ was utilized. Amplification reactions were carried out in Biorad (San Diego, CA, USA) with a program as 5 min denaturation at $94^{\circ} \mathrm{C}$ followed by 35 cycles of $94^{\circ} \mathrm{C}$ for $45 \mathrm{~s}$, annealing at $62.5^{\circ} \mathrm{C}$ (variable) for $45 \mathrm{~s}$ and extension at $72^{\circ} \mathrm{C}$ for $45 \mathrm{~s}$, with a final extension of $10 \mathrm{~min}$ at $72^{\circ} \mathrm{C}$. The PCR products were resolved on $2 \%$ agarose gel with $100 \mathrm{bp}$ ladder. Prior to sequencing the PCR products were cleaned with Exo-SAP (New England Biolabs, Beverely, MA, USA). Sequencing was carried out with a final volume of $10 \mu 1$ using ABI BigDye ${ }^{\mathrm{TM}}$ chemistry with manufacturer's protocol on ABI 3130 XL Automated DNA sequencer. Each PCR product was sequenced using reverse and forward primers. The sequences were aligned using BIOEDIT. The sequences were translated to get respective 


\section{Ml Macrothink}

Journal of Biology and Life Science ISSN 2157-6076 2013, Vol. 4, No. 1

amino acid sequences for the genes. These amino acid sequences were then aligned using CLUSTALW multiple alignment. The phylogenetic trees were prepared using BLAST (Altschul et al., 1990) in order to compare the changes with other members of family Bovidae.

Table 1. The primer pairs used for amplification of exons for GPX1 and DIO1

\begin{tabular}{|l|l|l|l|l|l|}
\hline SNo. & Name & Forward primer & Reverse primer & $\begin{array}{l}\text { Length } \\
\text { of } \\
\text { primers }\end{array}$ & Tm \\
\hline 1. & GPX_1 & GGAAAAGTGCCTGCACCA & AACTCCAGGGTGGATTTGAA & 38 & 60 \\
\hline 2. & GPX_2 & ACCCTGGAGTTACGCAACAA & GACATCAGGCATTCCTCCAC & 40 & 60 \\
\hline 4 & DIO1_1 & CTGGCACCTTCCTTCTGTCT & CAGAAAAGGAGCAGCTGGAG & 40 & 59.5 \\
\hline 5 & DIO1_2 & GCCTCTGCTAAATCGTGTGTT & GAAGCACTCCAGGTTTCTGC & 41 & 58 \\
\hline 6 & DIO1_3 & AGCCCCCACAACAAGAATTA & ATTTCATCCCCTGTGAGGTG & 40 & 63.8 \\
\hline 7 & DIO1_4 & CAGGCTTTTCAGAGGAGGTG & GGACAAAGAAGCAGGAGGAA & 40 & 65 \\
\hline 8 & DIO1_5 & TCTGCTTTTCCTCCTGCTTC & CCCCATGCTTAGTTCTAAAAGC & 42 & 59.5 \\
\hline
\end{tabular}

\section{Results and Discussions}

The amplified PCR products were of expected sizes. The sequences were aligned with one another to yield the consensus sequence of complete genes.

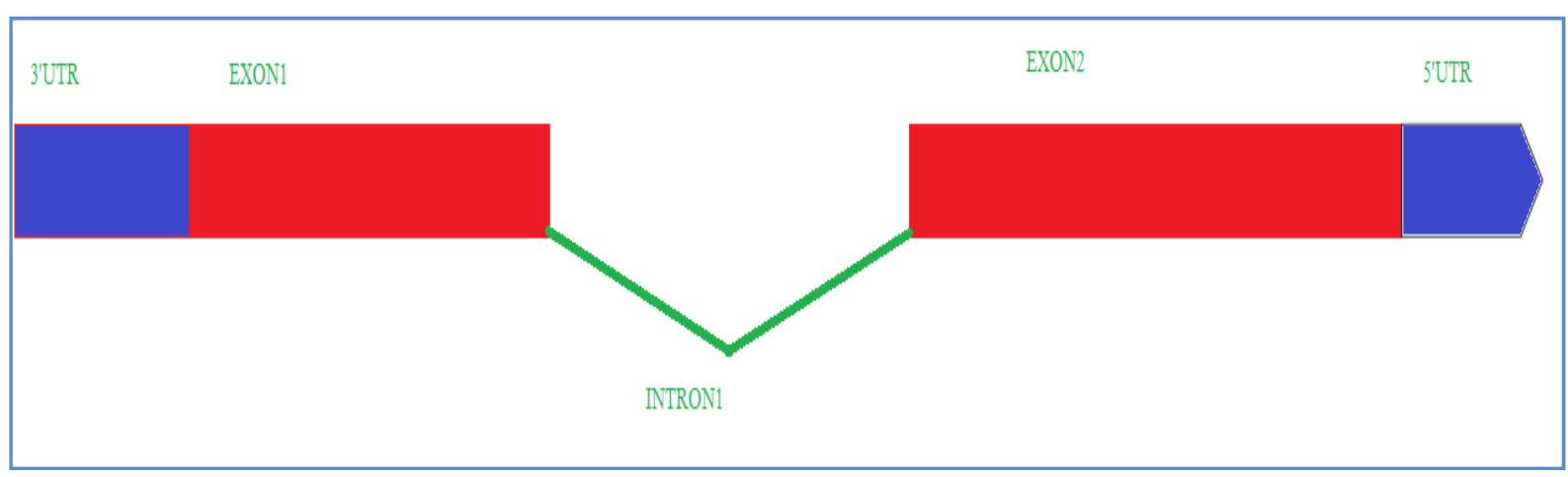

Figure 1.Structure of GPX1 gene showing Exon, Intron and UTR regions.

The sequence of GPX1 (JQ031269) gene consisted of 2 exons (Figure 1) of 1108 bases. In GPX1 gene, 5 SNPs were recorded and 4 were non synonymous, amino acid changes were distributed equally in both exon. In exon 1, A141G (Q5R) and G161A (A12T); and in exon 2 C785T (R132W) and A808T (S139R) changes were observed. Total of 3 transitions and 2 transversions were also found in GPX1 gene. 


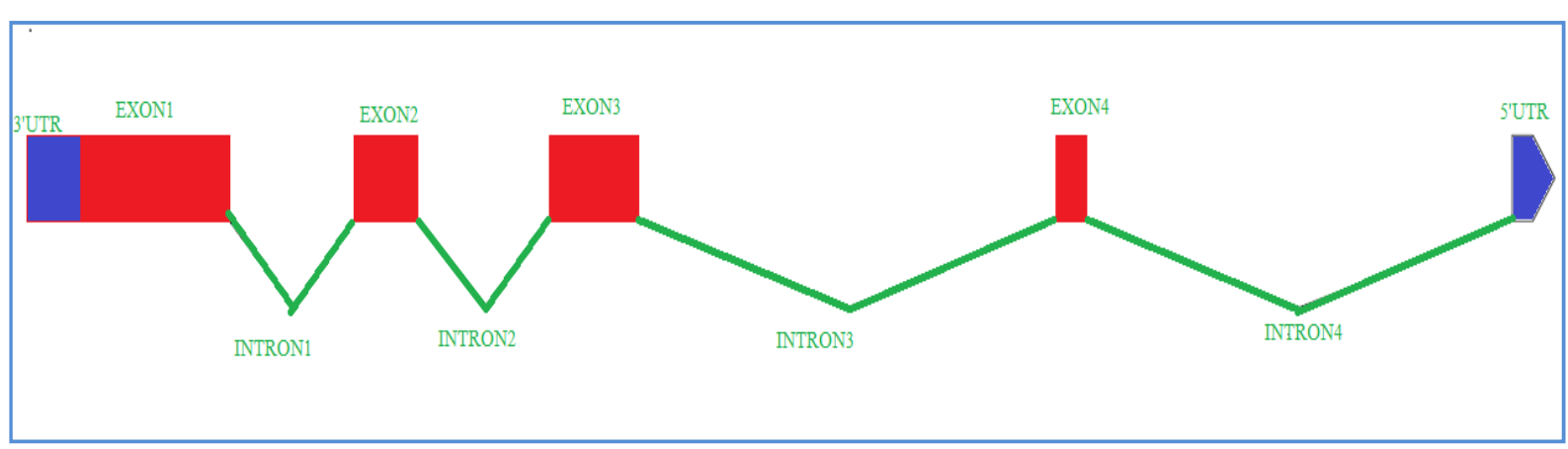

Figure 2. Structure of DIO gene showing Exon, Intron and UTR regions.

The sequence of DIO1 gene consisted of 3773 nucleotide bases (JQ791197). The DIO1 gene (Figure 2) codes for a protein of 249 amino acids. The 5'UTR region in the present study was of 123 bases while 3'UTR was 1059 bases long. A total of 4 SNPs were identified with 1 synonymous and 3 non-synonymous SNPs. Total of 3 transitions and 1 transversion were recorded in exonic region of DIO1 gene.

Buffalo specific SNPs of GPX1 and DIO1 gene and the resulting amino acid changes have been given in Table 2 .

Table 2. Buffalo specific SNPs of GPX1 and DIO1 gene

\begin{tabular}{|l|l|l|l|}
\hline Gene & Position & SNP & Amino acid Change \\
\hline Gpx1 & 141 & A-G & Q5R \\
\hline & 160 & G-A & L \\
\hline & 161 & G-A & A12T \\
\hline & 785 & C-T & R134W \\
\hline & 808 & A-T & S141R \\
\hline Dio1 & 188 & A-G & H22R \\
\hline & 215 & C-G & T31R \\
\hline & 941 & G-A & V146I \\
\hline & 1527 & G-A & T \\
\hline
\end{tabular}




\section{MInstitute Macrothink}

Journal of Biology and Life Science

ISSN 2157-6076

2013, Vol. 4, No. 1

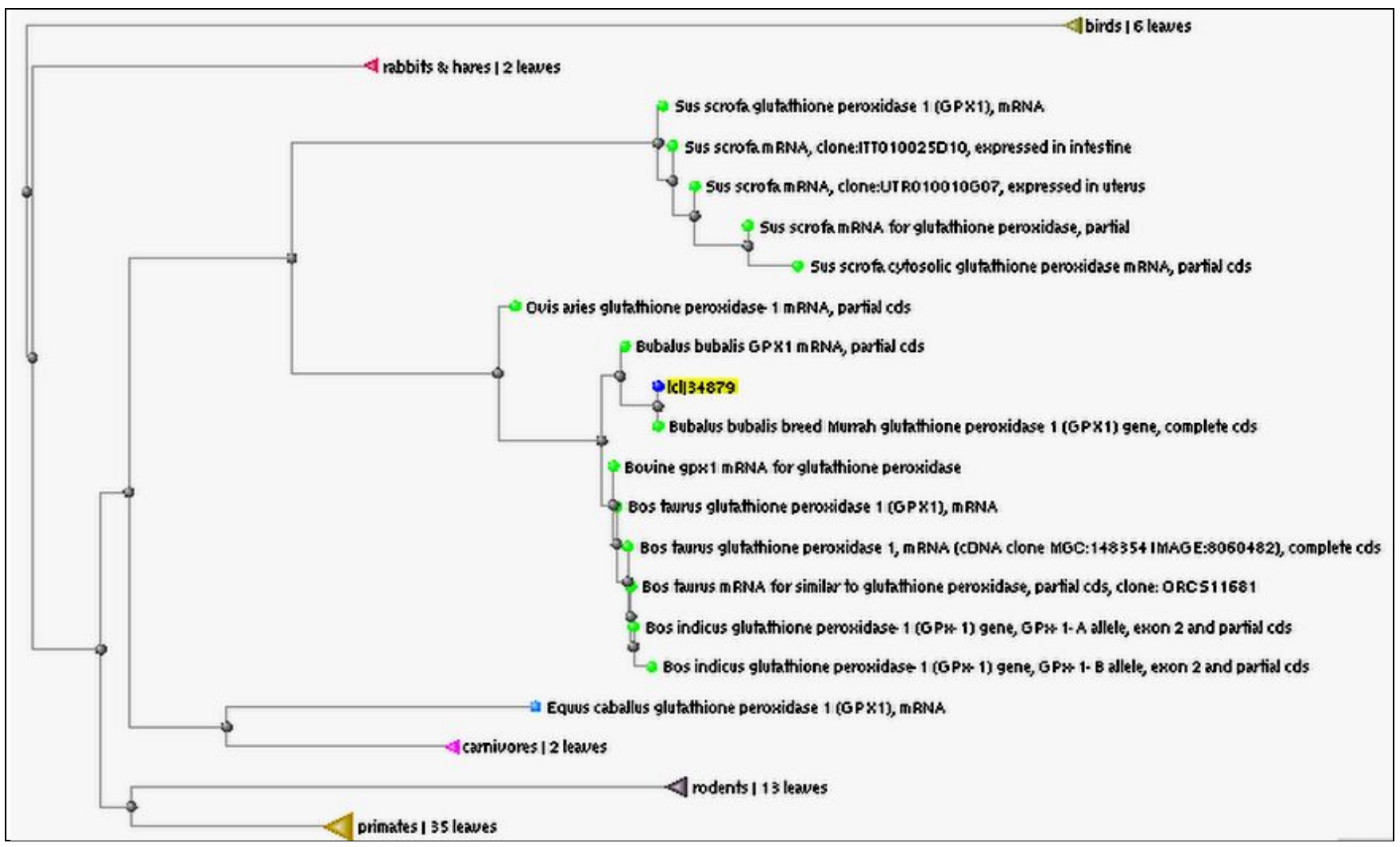

Figure 3. Phylogenetic tree of GPX1 gene based on nucleotide sequences.

The nucleotide sequences of the two genes were utilized using Neighbor-Joining algorithm (Saitou and Nei 1987) to construct a tree using BLAST (Altschulet al. 1990) and NCBI database. The branch of even-toed ungulates were analysed in detail. The nucleotide sequences for GPX1 genes obtained in the present study were similar to other sequences available in the NCBI database of Bubalus bubalis. They had similarities with another group of sequence from Bos taurus and Bos indicus followed by Ovis aries for GPX1 gene. All these sequence joined another group of sequence belonging to a Sus scrofa and Equus caballus (Figure 3). 


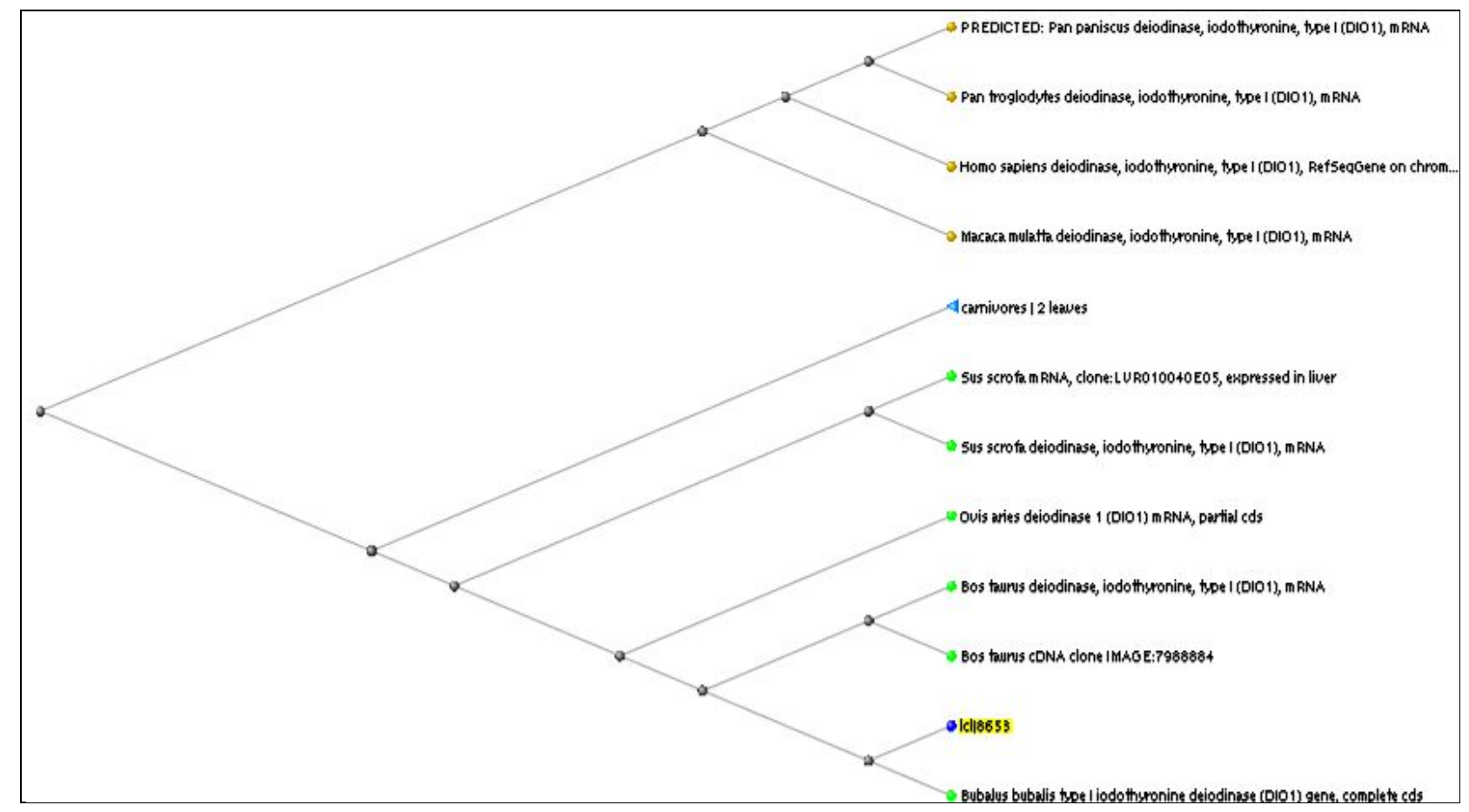

Figure 4. Phylogenetic tree of DIO1 gene based on nucleotide sequences.

The nucleotide sequence of DIO1 matched the other sequences already available in the NCBI GenBank of Bubalus bubalis. The next similar sequences belonged to Bos taurus and Bos indicus sequences followed by sequences of the species of Ovis aries and Sus scrofa. The two groups later joined with primate sequence of DIO1 (Figure 4).

The comparison of buffalo with Bos taurus, Mus musculus, Equus caballus, Gorilla, Pan troglodytes and Homo sapiens was carried out using CLUSTALW alignment for GPX1 amino acid consisting of 206 amino acids (Figure 5). The alignment revealed change at position 12 where buffalo has Threonine compared to Alanine in Bos taurus which seems to be highly variable. Similarly at location 5, 134 and 141 amino acids were different compared to other species with which the comparison was made. There were few instances where the amino acids were similar to other species but differed from buffalo and cattle (Bos taurus). The variable sites were 12, 16, 34, 187, 203 and 205

Similarly, the gene DIO1 seems to be highly conserved across the species. The CLUSTALW alignment (Figure 6) of the amino acid sequences of Bubalus bubalis, Bos taurus, Pan troglodytes, Gorilla, Homo sapiens, Mus musculus revealed only 3 changes A188G (H22R), C215G (T31R), G941A (I146V). The amino acid 5, 88, 130 and 144 seems to be variable among the species.

The phylogenetic tree constructed on the basis of nucleotide sequences for GPX1 and DIO1 revealed closeness of buffalo to cattle (Bos taurus on first node) followed by other primates. The sequences for GPX1 and DIO1 gene are reported for the first time in Bubalus bubalis at genomic DNA level. The analysis revealed that these two genes are highly conserved across all the mammalian species. The novel SNP's identified in present study can be used as DNA markers for association of these two genes with traits affected by selenium deficiency/toxicity. 


\section{MlMacrothink}

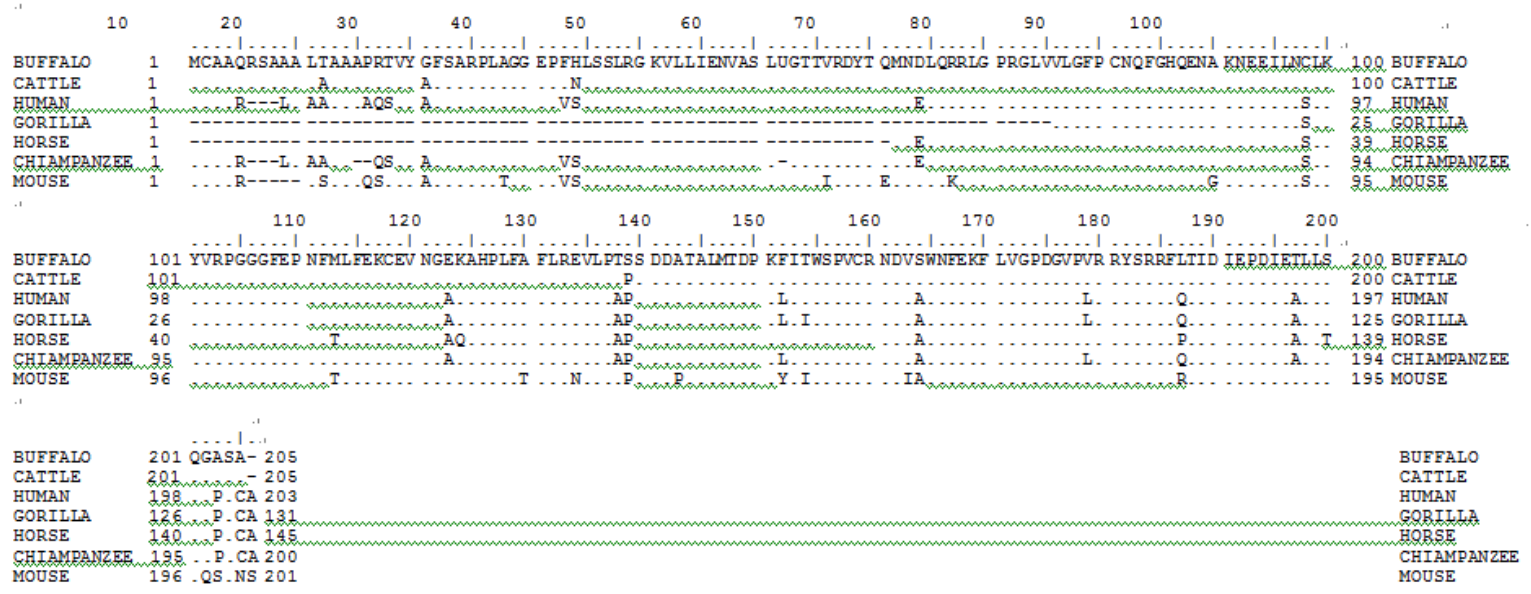

Figure 5. CLUSTAL W alignment of GPX1 gene based on amino acid sequences.

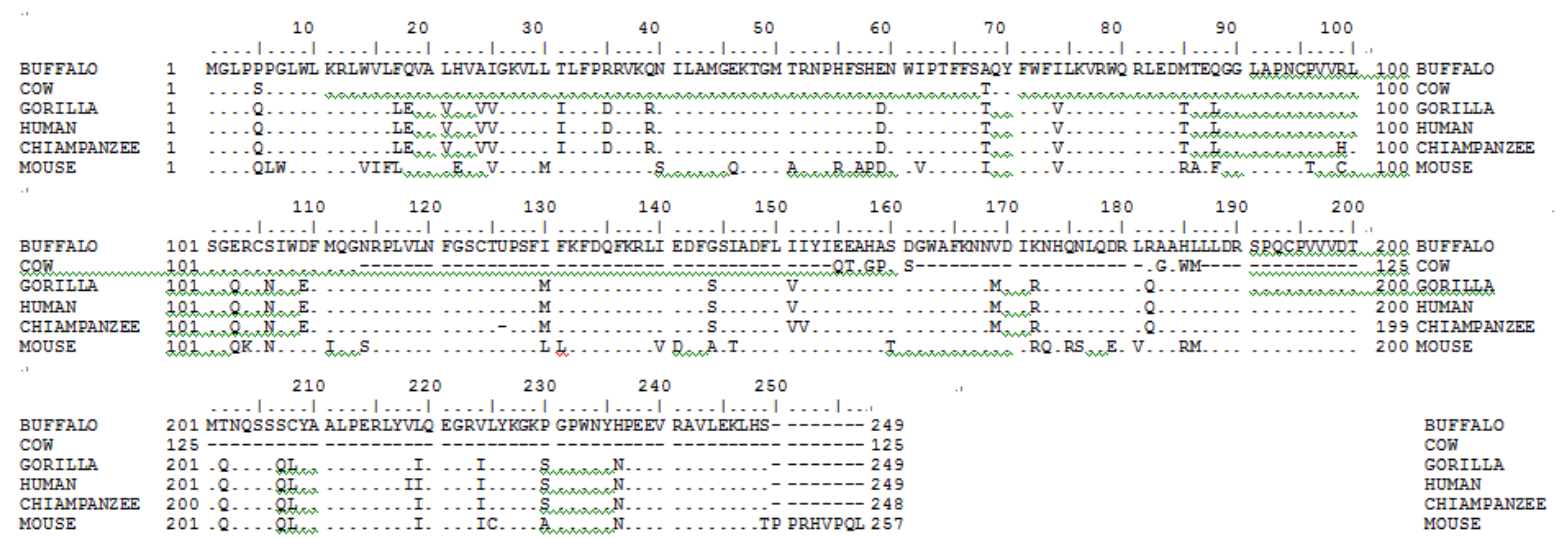

Figure 6. CLUSTAL W alignment of DIO1 gene based on amino acid sequences.

\section{References}

Aumann , K. D., Bedorf , N., Brigelius-Flohé, R., Schomburg, D., \& Flohé , L. (1997). Glutathione peroxidase revisited simulation of the catalytic cycle by computer-assisted molecular modeling. Biomed. Environ. Sci, 10, 136-155.

Altschul, S., Gish, W., Miller, W., Myers, E., \& Lipman, D. (1990). Basic local alignment search tool. Journal of Molecular Biology, 215, 403-410.

Burvenich, C., Van Merris, V., Mehrzad, J., Diez-Fraile, A., \& Duchateau, L. (2003). Severity of E. coli mastitis is mainly determined by cow factors. Vet. Res, 34, 521-562. http://dx.doi.org/10.1051/vetres:2003023

Flohe, L., Gunzler, W. A., \& Schock, H. H. (1973). Glutathione peroxidase: A selenoenzyme. FEBS Lett, 32, 132-134. http://dx.doi.org/10.1016/0014-5793(73)80755-0

Forstrom, J. W., Zakowski, J. J., \& Tappel, A. L. (1978). Identification of the catalytic site of rat liver glutathione peroxidase as selenocystiene. Biochemistry, 17, 2639-2644. http://dx.doi.org/10.1021/bi00606a028 
Gibson, R. S. (1990). Principles of Nutritional Assessment Oxford University Press. New York $N Y$, USA.

Gereben, B., Zeold, A., Dentice, M., Salvatore, D., \& Bianco, A. C. (2008). Activation and inactivation of thyroid hormone by deiodinases: local action with general consequences. Cell Mol Life Sci, 65, 570-590. http://dx.doi.org/10.1007/s00018-007-7396-0

Ingbar, S. H., Braverman, L. E. (1986). Eds. The Thyroid, J. B. Lippincott Company.

Malbe, M., Klaassen, M., Fang, W, et al., (1995). Comparisons of selenite and selenium yeast feed supplements on Se-incorporation, mastitis and leucocyte function in Se-deficient dairy cows. Zentralbl VeterinarmedA, 42.

Mehrzad, J. H., Dosogne, E., Meyer, R., Heyneman, Burvenich, C. (2001). Respiratory burst activity of blood and milk neutrophils in dairy cows during different stages of lactation. J Dairy Res, 68, 399-415. http://dx.doi.org/10.1017/S0022029901005039

Mishra, B. P., Prakash, B., Kataria, R. S., Kathiravan. P., Sadana, D. K., Das, G.C., \& Bhasin, V. (2010). Cytogenetic profiling and mitochondrial DNA analysis reveal existence of swamp buffalo population in Manipur state. Indian Journal of Animal Science, 80(1). 31-36.

Paape, M., Bannerman, D., Zhao, X., Lee, J. (2003). The bovine neutrophil: Structure and function in blood and milk. Vet. Res, 34, 597-627. http://dx.doi.org/10.1051/vetres:2003024

Rayman, M. P. (2000). The importance of selenium to human health. The Lancet, 356, 233- 241. http://dx.doi.org/10.1016/S0140-6736(00)02490-9

Reeves, M. A., \& Hoffmann, P. R. (2009). The human selenoproteome: recent insights into functions and regulation. Cell Mol Life Sci, 66, 2457-2478. http://dx.doi.org/10.1007/s00018-009-0032-4

Rocher, C., Lalanne, J. L., \& Chaudière, J. (1992). Purification and properties of a recombinant sulfur analog of purine selenium-glutathione peroxidase. Eur.J. Biochem, 205, 955-960. http://dx.doi.org/10.1111/j.1432-1033.1992.tb16862.x

Saitou, N., \& Nei, M. (1987). The neighbor-joining method: a new method for reconstructing phylogenetic trees. Molecular Biology and Evolution, 4(4), 406-425.

Schwartz, K., \& Foltz, C. M. (1957). Selenium as an integral part of factor 3 against dietary

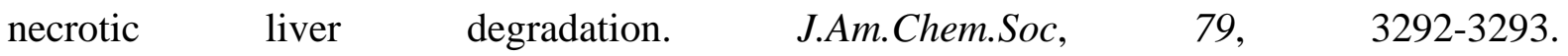
http://dx.doi.org/10.1021/ja01569a087

Smith, K. L., Harrison, J. H., Hancock, D. D., Todhunter, D. A., \& Conrad, H. R. (1984). Effect of vitamin $\mathrm{E}$ and selenium supplementation on incidence of clinical mastitis and duration of clinical symptoms. J. Dairy Sci 67.

Spears, J. W. (2000). Micronutrients and immune function in cattle. Proc.Nutr.Society, 59, 587-594. http://dx.doi.org/10.1017/S0029665100000835

St. Germain, D. L. (1994). Iodothyronine deiodinases. Trends Endocrinol Metab, 5, 36-42. 
http://dx.doi.org/10.1016/1043-2760(94)90119-8

Weiss, W. P., \& Hogan, J. S. (2005). Effect of selenium source on selenium status, neutrophil function, and response to intramammary endotoxin challenge of dairy cows. J. Dairy Sci, 88 .

Wendel, A., Kerner, B., \& Graupe, K. (1978). The selenium moiety of glutathione peroxidase. Hoppe-Seyler's Z. Physiol. Chem 359, 1035-1036.

\section{Copyright Disclaimer}

Copyright reserved by the author(s).

This article is an open-access article distributed under the terms and conditions of the Creative Commons Attribution license (http://creativecommons.org/licenses/by/3.0/). 